\title{
Tasavvuf; Modern ve Post-modern Çatışmasına Çözüm Olarak Geleneksel Bir Düşünce
}

\section{Sufism; a Traditional Thought as a Solution to the Modern and Post-modern Conflict}

\author{
Musa Kaval a,** \\ ${ }^{a}$ Dr. Öğr. Üyesi, Hakkari Üniversitesi, İlahiyat Fakültesi, Temel İslam Bilimleri, 30000, Hakkari/Türkiye. \\ ORCID: 0000-0001-8784-7762
}

\section{MAKALE BILGİSİ}

\section{Makale Geçmişi:}

Başvuru tarihi: 05 Ocak 2018

Düzeltme tarihi: 20 Ocak 2018

Kabul tarihi: 01 Şubat 2018

\section{Anahtar Kelimeler:}

Tasavvuf

Modernizm

Post-Modernizm

Tanr1

Kimlik Sorunu

\section{ARTICLE INFO}

Article history:

Received 05 January 2018

Received in revised form 20 January 2018

Accepted 01 February 2018

\section{Keywords:}

Sufism

Modernism

Post-Modernism

God

Identity Problem
ÖZ

Yeni bir dünya yaratma teşebbüsü olarak ortaya çıkan modernizm, temel dayanağı olan rasyonalist ve pozitivist yaklaşımı sayesinde doğa bilimlerinde rüş̧ünü ispatlamıştır. Ancak doğa kanunlarının keşfedilerek doğaya aykırı kullanılması hiç tasavvur edilemeyen sorunlara yol açmıştır. Doğanın bir parçası olarak insanoğlu da modernizmin olgucu değerlendirmelerine maruz kalarak tanrısal/ruhsal yönü inkâr edilmiştir. Dini inkâr eden ancak adeta bir din gibi kendi ölçütlerini dogmatikleştiren modernite sorgulanmaya başlanmıştır. Modernizmin yükseldiği hemen bütün değerleri inkâr eden post-modernistler karşı olmanın ötesinde herhangi bir bütüncül ve sistematik bir yaklaşım ortaya koymamaktadırlar. Şüphecilik ve kesinliğin olmadığı ancak bireysellik ve pragmatizmin sınırlarının mümkün mertebe zorlanmasının söz konusu olduğu post-modernizm ise modernizm kadar uzun sürmeden bir başka sorunlu evre olarak telakki edilmeye başlanmıştır. İnsan ve doğanın Tanrısal bağlarından koparılarak tek yönlü okumalara maruz bırakılması sonucu yaşanan kaosun çözümüne dair İslam'ın geleneksel düşüncesi olan tasavvufun doğru insan-âlem-tanrı sistematiği ortaya koyduğu savunulur. Bu çalışmada modern ve post-modernizmin neden olduğu sorunlar ve bunların çözümüne yönelik tasavvufun görüşlerine yer verilecektir.

\section{A B S T R A C T}

Modernism which has occurred as an idea of creating a new world proved the power with its main bases of rationalism and positivism. However, using natural laws that was discovered in nature caused some unpredictable problems because of running them against to nature. Like nature human being as a part of nature was exposed to some positivist evaluation and human soul was denied. Modernism was started to be criticized because of its dogmatic values but it denied religion because of dogma. Post-modernist activists not only opposed to all modern values but also they don't put forward any holistic and systematic approaches. Post-modern era was started to be criticized earlier than modernism because it asserts that there is no border for individuality and pragmatism even if having skepticism and certainty in everything. Humanity lives a chaos because of reading human being and nature in a strict way of modernism and post-modernism, however as a holistic Islamic traditional approach sufism is supported a solution for humanity. In this study problems caused by modernism and post-modernism are studied and solutions given by sufism are try to be ranked.

\section{Giriş}

İnsanoğlu kendi dünyasını kurgulayabilecek güçte bir varlıktır. Bu potansiyelini kullanma yönünde büyük bir azim ve cüretkârlık sergileyen insan, kendisinin üretmiş olduğu tarih içerisinde birçok inanç, kültür, felsefe, yönetim, yaşam tarzları ortaya koymuştur. Kendisi için tesis etmeye çalıştığı dünyada kimi zaman aynı dünyayı paylaştığı diğer canlı ve varlıklara da şekil vermekten sakınmamıştır. Aklı ile onlara hâkim olan insan her şeyin ölçüsüz bir akıl sonucu öncelikle kendi dışındaki dünyayı, sonrada hiç ummadık bir şekilde kendisine zarar verebilir. Kendi mutluluğunu güvence altına almak isterken egoizm ve hedonizme kaymanın örneklerinin medeniyetler tarihinde okuruz. Dinler tarihinde çok daha fazla anlatılan insanın ölçüsüzlülüğünün kimi zaman yaratmak istediği dünyanın yıkımına sebep olmaktadır.

Modern kavramı Hıristiyan inancı ile kurulmaya çalışılan yeni bir dünya kurma gayretiyle ortaya çıkmıştır. Yeni bir evre olarak temel belirleyici olan Hiristiyanlık inancı tarihin

\footnotetext{
* Sorumlu yazar/Corresponding author.

e-posta:kavalmusa@hotmail.com
} 
ilerleyen dönenimde başka bir modernist teşebbüsün müsebbibi olarak görülmüştür. İnsanın yaratma teşebbüsünün adı olan değişim bu manada tabi karşılanabilir. Ancak değişimin neden-sonuç, zaman-mekân ilişkisi açısından herhangi bir ölçüsünün olmayışı değişimin yenilik olmayabileceği düşüncesine yol açabilir. Dolaysıyla insanoğlunun değişim konusunda çok faal ancak sonuçları itibarıyla isabetli olduğu söylenemez. Bu durumun aklın adeta tanrılaştırıldığı modernizme eleştiri olarak ortaya çıkan post-modernizmde müşahede edileceği görülür.

Modern ve post-modern dünya algısı birbirine kökten zit görünse de post-modernizmin modernizmin sonuçlarının gözden geçirilerek yeniden düzenlendiği bir evre olduğu söylenebilir. Maddi dünyanın esas alındığı her iki sistemin merkezinde birey, onun özgürlüğü, ben merkezli bir yaşam tarzı salık verilmektedir. Modernizmin daha katı ve olgucu tavrına karşın post-modernizmin kaos, belirsizlik, çeşitlilik içerikli okumaları günümüz insanını ifrat ve tefrit kutuplarından birinden diğerine savrulmasına yol açmaktadır. Maddi alana dair sınırlı bilgi teorisinin nesnesi olan insanın ruhsal tatminsizliğinden kaynaklanan bu savrulmalardan kurtulmak isteyen insanoğlu asıl mekânı olan doğaya yönelme ve mistik tefekkürel uygulamalara giderek ağırlık vermesi, onun yaratmaya çalıştığını suni dünyaya karşı içsel bir tepki olarak görülebilir.

\section{Kavram Olarak Modern ve Modernizm}

Modernizm, bugün anlaşıldı̆̆ı mana itibarıyla Batı aydınlamacılığının köklerinin atıldığı 18 . yüzyıldan günümüze kadar süregelen bir medeniyet algısıdır. $\mathrm{Bu}$ tanımlamanın gerçek manada modern kavramının karşılığı olduğu konusunda farklı görüşler ortaya atılsa da Batı düşüncesinin genel vizyonu açısından kabul edilebilir bir nosyondur. İlk olarak 5. yüzyılda Latince "modernus" kelimesi ile kendini gösteren kavram yeni bir dönem olarak telakki edilen Hıristiyanlık sonrası evreyi, daha önceki Roma ve Paganist dönemden ayırmak amacıyla kullanılmıştır (Habermas, 1994: 31). İnanç ve kültür olarak yeni bir dönemin tarifi olarak kullanılan kavram 6. yüzyılda "modo" ifadesiyle "yenileyin" anlamıyla ilerleyen yüzyıllarda özellikle felsefi ve dini tartışmalarda kullanılmıştır (Rockmore, 1989: 233). Bugün Türkçe de kullandığımız "moda" yani "yeni bir tarz/yorum" ifadesine karşılık gelen "modo", "modernus" aslında devamlılı̆̆1 olan bir gelişimsel süreçten çok Batı medeniyetinin Hıristiyanlık öncesi ve sonrası dönemini yeni bir süreç olarak tarif ettiği bir kavram olarak görülür. Batı düşüncesinin birçok konuda referans olarak gösterdiği Antik Çağ ile ilişki kurulmak suretiyle, daimi yenilenme iddiasıyla modernizm gündemini korumuştur (Habermas, 1994: 32).

"Modo" kavramının sonuna "-izm" (ism) eklendiği ve böylece yenileşmenin bir akım ve devinim olarak kabul edildiği görülür. Hıristiyanlık kökenli yenileşme hareketinin bugün Batı dünyasının medeniyet algısının motoru konumundaki modernizme evrilene kadar değişik süreçlerden geçtiği tartışmasızdır. Günümüz insanı için modernizm ortaçağ zihniyetine karşı verilmiş haklı bir mücadelenin neticesinde kazanılmış büyük bir değer olarak görülmektedir. Kavramın ilk ortaya çıktığı dönem ile daha sonraki şartlar dikkate alındığında Hıristiyanlık inacının merkezde bir konuma sahip olduğu görülecektir. Tarihsel olarak bakıldığında modernizm bir yönüyle geçmişte yeniliğin motivasyonu olan bir olgunun (Hristiyanlık inancı) bir başka dönemde modernizmin önünde bir set oluşturarak başka bir yenilenmenin sebebi olmuştur (Kızılçelik, 1996). Modernizm'in Roma'nın çok tanrılı paganist kültürüne karşı tek tanrılı bir inancın temelinde şekillenmeye başlaması dinsel manada insanın fitratına doğru verdiği bir mücadele olduğu da söylenebilir. Ancak günümüzdeki manası itibarıyla araçsal olarak bakıldığında modernizmin tarihselliği büyük tezatlar içermektedir. Modern olanın zamanla eskimiş olmasından hareketle modernizm olgusal olarak bir "hakikat/ tam gerçeklik" değil bir tarihsel süreç olarak değerlendirilebilir.

\section{Modernizm}

Modernizm; Ortaçağın düşünce ve inançlarını yıkarak, çıkış motivasyonu olan Hıristiyan dogmatikliğini reddererek, pozitivizm merkezli, aklın tek ölçüt, bilginin nesnelliğine ulaşmanın hakikat olduğu iddiasındadır. Modernizm pozitivizm, rasyonalizm ve bunlardan çok daha etkili olarak aydınlanma temelleri üzerine sistemleştirilmiştir. Çünkü aydınlanma ile herkes için ortak doğru olan nesnellik sayesinde sadece bilimsel alanda değil evrensel ahlak ve hukuk aracılığıyla bireysel yaşamın rasyonal bir şekilde dizayn edilebileceği düşünülmüştür (Foster, 1983: 5). Ortaçağın dini ve siyasal yapısını ifade eden feodalizme karşı verilmiş haklı ve zafer ile neticelenen mücadele aslında Hz. İsa'dan sonra Hıristiyanların Paganist Roma'ya karşı vermiş oldukları savaştan çok da farklı değildi. Zira Pagan Roma mevcut siyasal ve kültürel yapı en azından yeni bir şey olan tek tanrılı Hıristiyanlığa firsat vermediği gibi Ortaçağ Avrupa'sı yeni düşüncelere müsamaha göstermiyordu.

Günümüz modernizmin öncüleri ya da savunanlarına baktığımızda yenilik anlamına gelen modernizm kavramını en azından belirli ölçütlerde sınırlandırdıkları düşüncesi ciddi anlamda tartışılmaktadır. Büyük oranda doğa bilimlerinde rüştünü ıspatlamış aydınlanma düşüncesinin getirdiği nesnellik ve olguculuk bütün hayatın tek gerçekliği olduğu algısı bu durumun temel nedenidir. Bu manada daha önce de ifade ettiğimiz gibi pozitivist, rasyonalist aydınlamayı hakikat yerine koyup modernizm tam da budur denildiğinde mantıksal olarak modernizmi inkâr etmişsiniz demektir. Dolayısıyla geçmişte Hıristiyanlık, Roma için yenilenme vesile olmuş, bir süre sonra aynı Hıristiyanlık geri kalmanın sebebi olarak gösterilmiş ve karşıt yönde bir modernizmi doğurmuştur. 20. yüzyılında özellikle son çeyreğinde dikkatleri çeken bir kavram olarak postmodernizm, modernizmin bilimsel olarak doğru bilgileri sunmuş olmasına rağmen insanoğlunun düşünceyi ve gerçeği tek yönlü sınırlandırma gayreti yüzünden giderek artan bir popüleriteye sahip olmuştur. Giddens, yöntem farklılığı olmasına rağmen modernizmin düşünsel olarak Ortaçağ felsefesinden tam olarak kopamadığını düşünür. Şöyle ki, kaderci Hıristiyanlık geleneğiyle bütün bağlarını koparan özgür aklın bu defa pozitivist ve rasyonalist aydınlanmanın geleceği kesinleştirme çabasıyla geleneksel katıcılığın bilimsel katılık şeklini alarak hayatı şekillendirdiğini söyler (Giddens, 1994: 48-49). Bilimsel olarak desteklenmiş olmasına rağmen olgucu aydınlanmanın katı sistematiği, anti tezini doğurarak modernizmin kavramsal sınırlarını aşıp gerçek manasına ulaşmasını sağlayacaktır. Zira modernizm dayanmış olduğu yöntemlere 
aşırı güvenerek kimi zaman aydınlanma düşüncesinin değişmez kesinliğini de reddebilmektedir (Lewis, 2000: 38).

Harwey'in (1999: 9) ifadesiyle modernizm sadece akla dayanarak ulaşılabilecek ilerlemeci inancıyla bilginin ve üretimin standardize edilmesinden kamusal alanın düzenlenmesine kadar hemen her konuda bir form oluşturma olarak tarif edilebilir. Modernizmin bu denli katı ve kuşatıcı yaklaşımı tarif ederken Harwey'in "belief" (inanç) ifadesini kullanmış olması yukarıda değinilen modernizmin çıkış sebebi ile gelinen nosyon arasında farkı ironik bir şekilde özetlemektedir. Doğrunun ve insanlık için tek çıkış yolunun, mutluluğun anahtarının ussal modernizmin elinde olduğunu iddia etmek başlıbaşına tezatlık arz etmektedir. Aklın kutsandığı modernizm düşüncesinde Tanrının varlığı, dünya ile irtibat1, yaratıcılık özelliği, yüce ve merhametli oluşu gibi insanın zihinsel ve duygusal yönüne hitap bilgiler tamamen inkâr edilmiştir (Faulkner, 1990: 60). Modern süreçte yaratıcı tek güç ussal kabiliyetlere sahip insanoğlunun kendi yaşantısıyla birlikte bütün canlıların yaşadığı çevreyi düzenleme, yeniden şekillendirme hakkına sahiptir. Sınanmış deneyimler, bilimsel doğrular ve teknolojik araçlar modern insana bütün sosyal süreçlerde idealizm gerçekleştirmeyi kurgulamıştır. Ancak aksine insanoğluna tek öznesi olarak tesis etmeye çalıştığı bu yeni süreçte beklenmedik bir şekilde aynı sürecin nesnesi rolünü biçmiştir. Dolayısıyla kontrol etme yetisini elinden kaçırdığı girdabın içerisinde birçok şey ile birlikte insanoğlu bir yerlere sürüklenmektedir (Berman, 1988). Hâlbuki profesyonellik ve her alanda uzmanlaşma ile planlanan yeni düzenden beklenenler farklıydı. Hayatın konformize edilip zamandan maksimum tasarrufun sağlanmasının hesaplandığ uzmanlaşma beklenmedik şekilde bireyi geniş çevresinden, buna bağlı olarak da tecrübe zenginliğinden uzaklaştırmıştır. Çevresel ve içsel olarak ilişkileri zayıflayan insanoğlu gerçek hayatta kopukluklar ve becerisizlikler yaşamaktadır. Örneğin bilgisayar teknolojilerinden çok iyi anlayan bir kişinin evinde ortaya çıkan basit bir su tesisatı arızası ile başa çıkamaması gibi. Bilgisayar teknolojisi ile kıyaslandığında çok basit bir işlem gerektiren su arızasına dair bilgisizlik modern insan için makul karşılanır. Musluk tamiri onun bilmesi zorunlu bir iş değildir, zira onun eğitimini almamıştır. $O$ iş için yetiştirilmiş insanlar mevcuttur ve herkes kendi işini yapmalıdır. Bireyin dış dünya ile ilişkisinin zihinsel, eğitsel ve ekonomik zincir olarak nasıl çalıştırılması gerektiği bu kadar net belirlenmiş sistem içerisinde aniden bozulan ve kısılamayan suyun kesinlikle normalden çok daha fazla paniğe ve huzursuzluğa sebep olacağı kesindir. Toplumsal olarak dağıtılmış uzmanlık rolleri ile kamu hayatında çeşitlilik sağlanmış olsa da bireyin potansiyellerinin minimuma indirgendiği görülür (Foster, 1996: 44-50).

Zaman tasarrufu sağlaması için geliştirilen teknolojiler yüzünden insanoğlunun giderek artan düzeyde zaman sorunu yaşadığı bilinir. Cep telefonları ve internetin sunduğu kolaylıklara rağmen modern insan için bedensel, ruhsal ve sosyal ilişkilerin sınırlarını daraltıp birden fazla yeni probleme yol açtıkları kabul edilir. Ellul'un (1965: 89) belirttiği gibi teknoloji aslında herhangi bir yöne doğrusal olarak gelişmez, arkadan itici bir güç onu yönlendirir. Teknolojinin sadece iyi ve güzel olana yönelmediği günümüz araçları değerlendirildiğinde kolaylıkla görülebilecektir. Yaygın bir çelişki olarak ortada duran iletişimi kolaylaştırmak için geliştirilen ve her gün yeni uygulamaları ile boy gösteren cep telefonları insanların, insan-insan ilişkisinin azalmasına yol açmaktadır. Öte yandan yüz yüze iletişimin getirdiği beden dili ve empatiden uzak şekilde geliştirilen gereğinden fazla iletişim sanallıkla birlikte yüzeyselleşmekte, inandırıcılığını yitirmektedir. $\mathrm{Bu}$ durum insanın insana bakışını da olumsuz etkilemektedir, zira insanlar dil üzerinden düşünce, duygu ve hal transferini gerçekleştirmektedirler.

Giderek artan ihtiyaçların bir sonucu olarak yeni kurum ve kuruluşların tesis edilmek zorunda kalınması modernizmin öngörüsel tarafinın eksiz olduğu gösterir. Zira sınırlandırılmış insan sınırlandırılmış toplumu doğurmuştur. Dolayısıyla birey ve kamu hayatında öngörülebilirlik ve devamlılık ciddi bir sorun olarak karşımıza çıkmaktadır. Geçen yüzyıl ile bulunduğumuz zaman dilimi içerisinde bireysel ve toplumsal değişimi zorlayan olay ve olgular sayıldığında günümüz insanın maruz kaldığı psikolojik, sosyolojik, ekonomik, siyasi, çevresel risklerin çeşitlenerek arttığı görülecektir. Dolayısıyla modernizmin şekillendirdiği istikrar ve devamlılık problemi tehdit oluşturmaktadır (Giddens, 1985). Halbuki modern herhangi bir kurumu incelediğinizde kuruluş amacı, misyon ve vizyonu açıkça beyan edilmiştir. Aile, kadın sorunları, eğitim, adalet, siyaset, ekonomi gibi hemen her alanda sık sık değişiklikler ve yeni birimlerin açılması durumu ile karşılaşırız.

Modernizmin bu katı sınırlayıcı tavrı dünyevi işlerde olduğu gibi dini, ahlaki ve manevi alanda da kendisini göstermektedir. Rasyonalite eşliğinde sekülerizmin dogma gibi dayatılmış olması paradoks olmanın ötesinde bir şeydir. İnkâr ettiği dinin metafizik olgularını insanlara kabul ettirmek için kullanılan iman olgusunu seküler alana birebir taşımak insanı ruhsal ve manevi olarak da minimize etmektir. Modernizmin akla dayanan kesin bilgileri, devamlı yenilik peşinde olması gereken salt ussal kesinliğin daima güncellenmesi olarak karşımıza çıkar. $\mathrm{Bu}$ durum insanoğlunun geleneksel/muhafazakâr yönünü tehdit etmektedir. $\mathrm{Bu}$ anlamda modernizm çıkış misyonunda uzaklaşmakla kalmayıp, yanlış bulduğu yöntem ve esasları ussal bir indirgemecilikle uygulamaya zorlamaktadır. Bu nedenle Bauman (1989) modernizmin, totaliter anlayış ve işleyişe benzediğini savunur.

Modernizm'in ortaya çıkış sebebi, süreci, hedefi, takip ettiği yöntem itibarıyla insanlık tarihinin genel seyrinde görülen değişimi ifade ettiği görülür. Kimi zaman çok sancılı olan bu değişim süreçleri 20-21. yüzyılda görüldüğü üzere maalesef çatışmacı ve yıkıcı olabilmektedir. Günümüz dünyasında değişimin temel dinamiği olarak farklı sebepler ileri sürülebilir. Ancak geçmişe dikkatle bakıldığında tıpkı modernizm kavramının inanç merkezli yeni bir yaşamaya geçiş olarak tarif edildiği gibi değişimin büyük oranda din merkezli olduğu görülür. Dinlerin Tanrısal bir çağrı olması insan için kuşatıcı bir mahiyet arz etmektedir. Dolayısıyla kuşatıcılığın sınırları insan tarafından her zaman tatminkâr bir şekilde karşılanmamıştır. Kimi zaman insanoğlu Tanrı'nın yeryüzüne müdahale etmesine rıza göstermemiştir. Hatta atalarının yapageldiklerinin tersine emirler getiren peygamberleri öldürmekle tehdit etmişlerdir. Semâvi âlemlere hüküm sürmesinden rahatsız olmadıkları Tanrının yeryüzüne müdâhale etmesine insanoğlu karşı durmaktadır. Kur'an-1 Kerim'de birçok ayette Allah'1 inkâr etme gerekçesi olarak bildirilen bu hakikat tanrılık iddiasında bulunan ve çevresi tarafindan da bu anlamda onaylana 
Firavun figüründe mâkes bulmaktadır. Firavun, kendisinin tanrılık iddiasını inkâr eden, gerçek Tanrı ve onun dinini tebliğ eden Hz. Musa'yı öldürmek ister. Çünkü Hz. Musa, Firavunun kurduğu dinle insanları köleleştirdiğini, halkı parçalara bölüp, zulmederek tanrılığını kabul ettirmesine karşı durmuştur (Mü'min, 26; Kasas, 4, 39). Hz. Musa'nın tebliğ etmiş olduğu dinden maksadın yeryüzünde kurduğu sapkın düzenin maddi olarak değiştirmek gibi sınırlı bir bakış ile değerlendiren Firavun, Hz. Musa'ya "Bizi yurdumuzdan çıkarasın diye mi geldin, ey Musa?" (Tâ'hâ, 57) cevabını vermiştir. Kendilerine gönderilen Peygamberlere inanmayan diğer topluluklar da benzer şekilde "Elbette sizi ya yurdumuzdan çıkaracağı, ya da mutlaka dinimize döneceksiniz!" (İbrahim, 13) tehdidinde bulunmuşlard1. Firavun'un zulmüne maruz kalan sindirilmiş topluluk da Hz. Musa'nın yolunun doğru olduğu kabul etmekle birlikte şöyle demişlerdir; "Biz sizinle beraber doğru yola uyarsak, yurdumuzdan atılırız." (Kasas, 57). Dolayısıyla tebliğ edilen yeni din mevcut bölgede bulunan iktidar gücü ve sistemin değişimi anlamında direkt bir tehdit olarak algılanmıştır. Firavun yeryüzünde ilah olarak sadece kendisinin hüküm sürdügünü iddia etmiştir; " Firavun: Ey ileri gelenler! Sizin için benden başka bir ilah tanımıyorum. Ey Hâmân! Haydi benim için çamur üzerine ateş yak (ve tuğla imal et), bana bir kule yap ki Musa'nın ilahına (tanrısına) çıkayım; ama sanıyorum, o mutlaka yalan söyleyenlerdendir, dedi." (Kasas, 38); "Firavun: Ey Hâmân, bana yüksek bir kule yap; belki yollara, göklerin yollarına erișirim de Musa'nın İlahı'nı görürüm! Doğrusu ben onu, yalancı sanıyorum, dedi." (Mü'min, 36-37). Ayetlerde bildirildiği üzere yeryüzünde kesinlikle inkâr edilen tanrının inşa edilecek bir kule ile göklerde bir yerde bulunabileceği itiraf edilmektedir.

Firavun gibi modernizmin inşa ettiği deney ve gözlem kulelerinden bakıldığında yeryüzünde Tanrısal bir sistemin olduğu ispat edilemediği için yeryüzü tanrılaştırılmış akıl ve bilim ile dizayn edilmelidir. Eğer bir tanrı varsa da Firavun'un tasarlattığ ispatlanmış bir tanrı olmanın ötesine geçmemelidir. Modernizmin tesis etmeye çalıştığı yeryüzü ve ruhsal âlemlere dair düzenlemelerdeki yanlışlara rağmen 1srarı Firavun düşüncesi ile benzerlik göstermektedir. İnsanlık tarihi içerisinde kısa denilebilecek bir zaman dilimde yanlışlıkları ve eksikleriyle ciddi tartışmaların odağına oturtulan modernizm Firavun örneğinde olduğu gibi en büyük iddiası ile çözülecektir diye düşünmemek elde değil. Firavun döneminde sihir oldukça gelişmişti ve Firavun'un sihirbazlar aracılığıla Hz. Musa'yı alt edeceğini düşünüyordu. Ancak yeryüzü ilmi ile semâvi ilimlerin birbiriyle çelişmemesi nedeniyle göz boyaması olan sihir hileleri tanrısal ilim olan mucizeler tarafından yutulmuş, içselleştirilmiştir. Ağaçtan asanın suni bilgilerle biraya getirilerek hareket ediyormuş izlenimi uyandıran ip ve sopaları yutması doğanın/fitratın doğal olmayana galibiyeti olmuştur. Metafiziğin maddeye olan galibiyetinin dönemin sihirbazları nasıl şaşkınlıkla karşılamış, Hz. Musa'nın dinine tabi olup Allah'a iman ettiyse (Tâ'hâ, 70) insanı sadece zahiri akıl ile değerlendiren modernizm de fitratın ve hakikatin karşısına delil olarak sunduğu katıksız nesnel rasyonalizm aracılığıyla kendi tezini çürüteceği umulabilir. Tam bu noktada modernizme karşı tepki olarak ortaya çıkan post-modernizmin aklın ve bilginin sabitliği konusundaki eleştiri akla gelmektedir.

\section{Post-modernizm}

Modernizm'in katı ussal sistematiği üzerinde aşırı 1srarcı olması post-modernizm ortaya çıkarmıştır (Giddens, 2012: 51). Bir tepkinin ifadesi olarak ortaya çıkan post-modernizm kendini tarif ederken öteki olan modernizm ile direkt ve tam bir karşıtlık ilişkisi kurmuştur. Tepkisel hareketlerin hepsinde karşılaşılan bu durum "biz" in inşasında var olan "öteki" dışlanırken aslında sadece "biz"i değil "öteki"ni de şekillendirir (Hall, 1998: 41). Bu gerçeğin bir işareti olarak post-modernizm kendini şekillendirirken yakınlık ve benzerliklerden yararlanmayı hiç düşünmeden muhalif olmayı yeğlemiştir (Connor, 2001: 347-350). Aynı zamanda öteki olan modernizmi de değişime ve yenileşmeye sev etmiştir.

Modernizmin akıl ve bilim 1şığında ortaya konmuş değişmez gerçekler çerçevesinde bir düzen inşa etmiştir. Temelden buna karşıt olan post-modern düşünce ise gerçekliğin ve doğrunun değişmezliğini reddeder ve hatta insanoğlunun böyle bir kesin doğruluğa ulaşamayacağını savunur (Mourad, 1997: 116). Post-modernistlere göre doğrunun ve nesnelliğin bilim adamlarının tekilinde olması büyük bir yanlıştır, zira hakikat cinsel, sınıfsal, etnik ve kültürel farklıkların dikkate alınması koşuluyla bütün insanlığın hep birlikte ortaya koyabileceği bir şeydir (Nelson, 2001: 294). Dolayısıyla gerçeklik olgusu bütünü oluşturan her bir birey tarafindan çok yönlü bir gerçeklik arz etmek durumundadır. Herkesin söz sahibi olduğu bu anlayış doğrultusunda bilimsel yaklaşım temelden değişmektedir. Çünkü modern durumda kesinliği olan tek bir doğrunun yerini kesinliği olmayan ve üstelik çoklu bir bilim dünyası ortaya atılmıştır. Bilgiye erişimi noktasında post-modernistler olgucu yaklaşım yerine bireysel ve yerel faydacılık merkezli oldukça göreceli bir yöntemi savunurlar (Scott, 1997: 19). Post-modern şüpheciliğin sonucu bütün disiplinler ve insani her türlü farklılık değerlendirmeye katılmasına rağmen doğru ve doğrunun objektifliği açısından elde olan sadece belirsizlik ve karmaşadır (Cullenberg 2001: 8-15).

Post-modernizmin herhangi bir kesinliğe ulaşmamasında bilimsel bütün metod ve yöntemlere şüpheyle yaklaşılması gerektiği temel fikridir (Richardson, 2000: 298). Hatta zaman ve mekâna karşı da şüphecilik savunulur (Rosenau, 1992: 71-78). Bu durumun bir sonucu olarak herhangi bir argüman en az diğeri kadar değerlidir zira nesnelliğin ne olduğu konusunda herhangi bir standart olmadığı için doğrunun ne olduğu müphem olarak kalacaktır. Postmodernistlerin böyle bir gayesi de yoktur çünkü herkes kendi doğrusunu savunup diğeri pekâla inkâr edebilir. Sonuç olarak herkesin ikna olmadığı, tartışmanın bir sonuca evrilmediği durumda herkesin düşüncesi doğrunun bir boyutu olarak kabul görüp, çoklu gerçekliğin anlaşılması sağlanmıştır (Detmer, 2003: 65-70). Zaten dünyadaki her şey birbiri ile herhangi bir sebep-sonuç ilişkisi ortaya konmamış olsa dahi nihayetinde ilişkilidir (Rosenau, 1992: 112-113).

Post-modernizm, insan ile birlikte bütün dünyayı okurken ileri sürdüğü belirsizlik ve değişkenlikten öte (Hassard, 1999: 188-9) modernizmin ürettikleri bozguna uğratma teşebbüsü olarak görülebilir (Connor, 2001: 33). Modernizme karşı herhangi bir düzenli ve bütüncül bir sistem ortaya konulmaması, belirsizlik ve karmaşa ile birlikte herkesin sürece dâhil edilip menfaat sağlayabileceğini iddiasında fakat kendi içerisinde çelişkiler 
barındırdığı için post-modernizm anarşizm olarak tanımlanmıştır (Ronenau, 1998: 37). Post-modernizmin kamusal ortak akıl, adalet ve ahlaki değerler bağlamında gerçekleştirilemeyecek bir akım olduğu düşünülür (Lawrance, 1989: 310- 319). Bu eleştirinin kökeninde yatan sebep; ussallık ile kurgulanmaya çalışılan modernizme karşı herhangi bir sistematik önermek yerine tamamen reddiyeci bir tavrın benimsenmiş olmasıdır. Bununla birlikte potmodern düşüncenin ortaya attığı tezlerin zamanla kendi içerisinde kendini yenileme ihtiyacını hissetmesi de eleştirilir. Ancak kendini yenileme eğilimi modernizmde de görüldüğü için bu eleştiri mantıksal düzlemde doğrulanmaktan uzaktır. Zira her yeni düşünde eskisine göre doğal olarak bir yenilenmeyi de beraberinde getirir. $\mathrm{Bu}$ bağlamda bakıldığında Dow'un (2001: 60-79) ifade ettiği gibi modern ve post-modern evrelerin verdiği mücadele aslinda kendilerinden sonraki sentez evresinin ortaya çıkması için tez-antitez çatışmasıdır. Post-modernizmin iddialarına bakıldığından anti-tez olmanın ötesine geçemeyen bir reddiyecilik barındırdığı tartışmasızdır. Dolayıyla modernizmin ürettiği bilgi ve kültüre karşı kökten bir alternatif sunması şimdilik söz konusu değildir. $\mathrm{Bu}$ manada post-modernizm kendisini karşısındakine göre tarif eden herhangi bir karşıt/zıt olmanın ötesine geçip kendiliğini bulamamıştır. Modernizmin yanlış ve eksik olduğu savunucuları tarafindan da kabul edilmişken beyan edilen kusurların kriter kılınarak karşıt olarak konumlandırılmak zaruri olarak belirsizlik, değişkenlik, karmaşa ve subjektiflik arz etmek durumdadır.

İnsan ile birlikte bütün dünyayı kendi standartlarına göre şekillendirmeye çalışan modernizm, Tanrısal güçlere ve ruhun varlığına hiç yer vermemiştir (Giddens, 2012: 101). Firavun'a benzerlik arz eden bu eğilim dinin dışında kültürel ve günlük yaşama da etki etmiştir. Hemen bütün kültürlerde geçmiş, an ve gelecek dinsel inanç öğeleri ile anlamlandırılırken modern dönemde batıl inanç olarak kalan ve pek de işlevi olmayan zaman ve yaşanılan işe ilgili düşünceler akıl ve risk değerlendirmeleriyle anlatılmaktadır. Yani modern insan hayatını inanç merkezli olmaktan çıkarıp akıl ve içinde bulunulan durumun rasyonel kritelerle değerlendirerek yaşamayı tercih etmiştir (Diggens, 2000: 3841). Din-kültür-zaman arasındaki yeni ilişki ussal olan ile yeniden düzenlendiği için metafizik olanın toplumsal paylaşım alanlarından uzaklaşması söz konusu olmuştur. Aklın öncülüğünde ruhsal ve toplumsal olanın totaliter bir indirgemiciliğe maruz kalması, karşı tepki olarak postmodernizmde yer edinememiştir (Rosenau, 1992).

Post-modernizm kültürlerin, kültürleri oluşturan dinlerin, geleneklerin ve bunların bir sonucu olarak hayat tarzlarının çeşitliliğini savunur (Spicer, 2005: 671). Modernizin aksine post-modernizmde herhangi bir sınırlandırma, yönlendirme ve zamansal öngörülebilirliğe dair hiçbir uğraşa yer yoktur (Lyotard 1985). Bu nedenle post-modern düşüncede topluma dair standardize edilmiş bir kurama rastlanmaz (Kellner, 1994: 229). Çeşitliliğin doğurduğu dağınıklık ve parçalılık, zamansal ve mekansal kaos ve süreksizlik post-modernistler için sorun olarak nitelendirilmediği için bunların aşılmasına dair herhangi bir teşebbüs söz konusu olmaz (Harvey, 1999: 60). Hayatın tümüne dair sergilenen bu belirsizliklerin temelinde bilimin ve aklın modernizmde olduğu gibi öncül bir işleve sahip olmadığı görülür, zira post-modern düşüncede bilginin göreceliliği ve çeşitliği esas kabul edilir (Lyotard, 1985). Modernizm'in Tanrısı olan aklın her şeyin belirleyicisi olduğunu onaylamayan bu yeni evrede aklın ve deneyin ortaya koydukları sadece pragmatik sonuçları açısından göreceli bir değere sahip kılınmıştır. Genel-geçer bir hakikat olma vasfinı yitiren rasyonalitenin içinde gelişen post-modernizm çevreye herhangi bir zamansal ölçüt de getirmeden insana sağladığı faydadan başka bir şey değildir (Connor, 2001: 45-47).

Post-modernizmin vaad ettiği sınırsızlık, çoğulculuk, görecelilik ve zamansızlık modernizmin dayattığı indirgemeciliğe karşı daha hoş görülebilir (Beckford, 1966: 30). Ancak henüz sınanma aşamasında olan postmodernitenin insanlık için çözüm olduğunu söyleyemeyiz. Yukarıda ele alındığı üzere modernizmin çözüm olarak ortaya sürüp katı şekilde uygulamaya koyduğu düşünce yapısı giderek artan ve ağırlaşan sorunlar nedeniyle insanın anlam dünyasında kargaşaya sebep olmuştur (Murphy, 1995). İdeal formülizasyon ile sunulan modernizm bir sonucu olarak post-modernizm yaşanmak durumundadır. $\mathrm{Bu}$ anlamda Harvey'in (1997: 137) de dediği gibi postmodernizm, modernizim kendi içinden çıkardığı bir krizdir. Araştırmacılar modernizm ve post-modernizmin birbirinden ayrı, biri diğerine karşıt bambaşka bir şey olduğu olmadığı konusunda genel bir kanıya sahiptir. Prensipler ve işleyiş bağlamında etki-tepki, zaman ilişkisi açısından önceliksonralık, tecrübe edinimi sonrası gözden geçirilen sebepsonuç argümanları nezdinde modernizm ve post-modernizmi ayrık olarak değerlendirmek söz konusu edilemez. Dolayısıyla modernizmi yerden yere vuran postmodernistler de bu iki sürecin insanlık tarihi için henüz tamamlanmamış birer geçiş süreçleri olduğunu kabul ederler (Cullenberg, 2001: 22). Dolayısıyla bütün yaşamı kuşatan kültürel unsurların modern dönemde küreselleşmeyle birlikte ağır basana doğru yönelmesi söz konusu iken postmodernizm ile birlikte bırakın kültürel özerklikleri aynı alt kültür içerisindeki bireylerin dahi kendi kişisel kimlikleri ve farklı etkileşim tercihleri temel bir hak olarak kabul edilir (Murphy, 1995: 192-207). Dolayısıyla bilgi ve teknolojinin sahibi olma ayrıcalığı ile modern düşüncenin küreleşme üzerinden bütün diğer kültürlere dayattığı yaşam tarzının doğru kabul edilmediği post-modern düşüncede hangi kültür olursa olsun insanın eylemselliğini kontrol eden bir normlar silsilesi olarak kabul görmemektedir (Murphy, 1995: 173).

Kültürel homojenlik yerine olabildiğince özgürlük ve özgünlüğe izin veren post-modernizmin, modernizm bunalımından sonra insana rahatlama hissi verdiği düşünülebilir. Doğrunun, iyinin ve mutluluğun standardize edildiği modernizm ve onun araçlarıyla kendini doğal haliyle ve özgürce ifade edemeyen insanoğlunun kendine yabancılaşması söz konusudur. Ne kadar doğru ve güzel kurallarla donatılırsa donatılsın insanoğlunun özgürlük sorununun önüne geçilemez. Zira insan zıtlıklar dolu bir varlık olması nedeniyle sadece doğru ve güzel olan ile yetinmeyecektir. Dolayısıyla insanın kendisi için doğru ve güzel olanı keşfetmesi gerekmektedir ki bu bazen çirkin ve kötü olanın tecrübesinden sonra fark edilebilir. İnsanın kendisi ve çevresi ile ilgili hakikat arayışının doğal mekân ve zamanlama ile yakından ilişkisi vardır. Modernizm çevrelediği doğrular düzeninden tabiat, doğal tabiat olmaktan çıkarılmıştır (Diggens, 2000: 51). Dolaysıyla doğallığını kaybetmiş bir çevrede insanın hakikati keşfedebilmesi kolay değildir. İnsan için faydalı olanların net olarak belirlenmiş olduğu modern yaşamda bilim ve teknoloji koşutunda tabi doğadan kopan insanın nasıl bir 
sonuca varacağı bilinemez (Murphy, 2000: 50). Modern insanın gelişmiş teknoloji ve tıp ilimdeki hızla ilerlemeye rağmen sağlık sorunların azaldığı, ya da gıda teknolojisindeki gelişmelere rağmen sağlıklı beslenme konusunda çok yol katettiği düşünülemez.

\section{Modernizm ve Post-modernizm'in Kimlik Sorunu}

İnsanoğlunun dış dünyaya yönelik değerlendirmeleri ve tavırları kendi benliğine yönelik tanımlamalarından bağımsız düşünülemez. Kendine dair bilgisi hangi yönde artmışsa insanın ortaya koyduğu düşünce ve eylemselliği o yönde yükselir. Modern düşüncede akıl ve bilimin öncülüğünde şekillendiği için insanın benliğinde uzmanlık alanı olan mesleği büyük önem taşır (Kellner, 2001: 207). Meslek edinimi için sarf edilmiş uzun formel eğitim süreçlerinden sonra birey kendiliğini topluma kabul ettirmiş olur. $\mathrm{Bu}$ durum modernizmin bireysel gelişimi gayesine hizmet ederken diğer taraftan mesleğe dayalı sınıflar bir tabakalaşmaya da sebep olmuştur. Bireyselliğin ve özgürlüğün ateşli savunucu olarak modern düşünce değişime açık bir kimlik edinmeye elverişli olması sonucu çok katmanlı bir yap1 ortaya koyar. Her yenilik beraberinde başka bir grup aidiyetine sebebiyet vereceği için çok katmanlılık kaçınılmazdır. Bununla birlikte modern düşüncenin bir sistematiği olduğu için toplumsal hayatta kabul edilmiş kimlikler ve roller çeşitli norm ve geleneklere göre şekillenmek durumundadır, onları kökten inkâr etmek yerine onunla etkileşim içerisinde bulunarak, beklentileri dikkate alarak dönüşüm ve yenilik sunması beklenir. Modernizmde yeni bir kimlik ortaya koyma serüveni geçmişi inkâr etmeden bireysel gelişim araçlarını da kullanarak farklı ve yeni bir öteki kurma sürecidir. Bu uğraş da birey ve toplum iki ayrı etken olarak kimlik inşa etmede dikkate alınmak durumundadır (Kellner, 2001: 195-205).

Kellner'in ifadesine benzer şekilde psikolojide de kimlik; bireyin kendine dair bir algılama olmakla birlikte diğeri olanlara ilişki ve etkileşimlerin dönütleri ile şekillendirilen bir süreç olarak tarif edilir (Bilgin, 2001: 156). Kimliğin çevreden yalıtılmış ya da onu inkâr ederek başka bir ayrık kimlik söz konusu olmayan modernite de meslekten sonra toplumsal kimlik başat role sahiptir (Kellner, 2001: 207). Toplumsal değişimin hiç durağanlaşmadığı gerçeğini de göz önünden aldığımızda birey kendi kimliğini salt kendiliği içinde belirli bir zamanda değil, aksine diğerleriyle etkileşim içerisinde bulunulan uzun bir gelişim sürecinde geliştirir (Bilgin, 76-78). Süreç alması ve değişimin her alanda hızlı gelişmesi sonucu bireyin kimlik edinimi kolay olmayacaktır. Her bir dinamiğin kendi içerisindeki değişim sonucu bireyde oturtulması beklenen kimlik ve benlik algısı çelişkiler doğurabilir. Bu manada kimlik kavramının doğasından kaynaklanan bir karmaşanın var olduğu tezi günümüz dünyasında dikkate alınmalı (Buckingham, 2008: 1-5).

Bireyselliği, özerkliği ve özgünlüğü, insan aklının kendini gerçekleştirmesi için yücelten modernizmin arzu ettiğinin aksine post-modern ayrışma ve karmaşasının sebebi olmuştur (Hall, 1995: 105-126). Çünkü modernite evrende aklı ile öne çıkan insanın bütün doğayı ve doğasal düzenin tek sahibi gibi algılamıştır. Kendi ürettiği kültürü, doğanın önüne geçiren modernite kurguladığının aksine doğanın değişmez hakikatleri tarafindan yenilgiye uğratılmıştır. Hegel'in tinsel dünya yaratma olarak tarif ettiği insanlar tarafından kurulmak istenen bu doğa dünyası kadar düzenli değildir. Modernitenin inkâr ettiği Tanrı tarafından kurulmuş doğa dünyasında sadece ussal kurgulamalar yoktur. Her ne kadar insanoğlu kendi ürettiği tinsel dünyada Tanrı'dan söz etse de aslında bahsi geçen insan tarafından üretilmiş tanrıdır, gerçek Tanrı değildir (Hegel, 2003: 55). Dolayısıyla modernitenin Tanrısı akıl tarafından şekillendirilen bütün yenilik ve dönüşüm çabalarına rağmen birey kimlik buhranı ve yabancılaşma sorunu ile karşı karşıya kalmıştır. Yukarıda bahsi geçen Firavun örneğinde olduğu gibi insanın kendi aklını Tanrısallaştırarak dinsel bir meşrulaştırma aracını da kullanmak suretiyle ortaya koyduğu deneyimler doğa/fitrat denilen ilahi yaratılıştan uzaklaşmasına sebep olmuştur.

İnsanlık için ideal olan bireysel ve toplumsal yaşamı vaad eden modern toplumlarda ahlaki dejenerasyonun başta ekonomi olmak üzere hemen her alanda ses getirecek derecede arttığı görülür (Diggens, 2000: 89-94). Bu durumun sonuçları olarak modernizm sonrası dönemde modern değerlerden kopuş yaşanmıştır (Best, 1998: 47-48). Modern düşünde üretilmiş bilginin ekonomik bir karşılığa tekabül etmesi onu, küreselleşmeyi dayatan kapitalizme yönlendirmiştir. Modernizmin doğurduğu kapitalizm ile post-modernizm arasında birebir ilişki söz konusudur (King, 2005: 519). Çünkü modern düşüncenin doğurduğu ekonomi, üretim-tüketim anlayışının bir sonucu olarak kapitalizm yukarıda ele alındığı gibi modernizmin insan, din ve doğa ya dair kendi düzenini kurduğu bir başka alandır. Modern düşüncenin her şeyi kendi kotrolü altına alma eğilimi ekonomide de kendini kapitalizm eliyle gerçekleştirmektedir. Bunun en bariz örneği de modern insanın hayatının vazgeçilmezi olan hemen her şeyin sigortalanması ihtiyacıdır (Diggens, 2000: 44).

Kapitalizm insanın sadece ekonomik tercihleriyle sınırlandırılamaz. Sınırlamacı ve indirmegici düşünsel arka bir planı olan kapitalizm insan ilişkileri bağlamında da "tüket-at" şeklinde algılanmasına yol açmıştır (Harvey, 1997: 319). İnsanın ve onun ürettiği bütün değerlerin kısa süreli faydacılık uğruna heba edildiği modern dönemde ilişkiler ve etkileşimler büyük oranda zorunlu sebeplerden kaynaklanmaktadır. Geçmişle kıyaslandığında ciddi oranda artış görülen bu ilişki yoğunluğu göreceli ve geçicidir (Simmel, 1969). Çünkü topluma dair her okuma ve anlamlandırma geçici birer yargıdan ibarettir (Hugman, 2003: 1026). Modernizmin insana dair sınırlı, doğaya/fitrata karşı cüretkârlıkla bezediği yeni düzenin bir sonucu olarak bireysel benlik inşası, tüketim kültürü ile teknolojinin etkileşimli dönüşümü sonucu kararlılıktan uzak, toplumsal çevreyi teknolojik bir ürün gibi sadece kısa süreli kullanılacak bir nesne olarak algılaya yöneltmiştir. Sonuç olarak da post-modern dönemde geçici, amaçsız, plansız, pragmatik, arzu tatmini merkezli bencil bir benlik algısı olan insan ortaya çıkmaktadır (Dunn, 1998: 66). Tüketim kültüründen alışılagelen geçici arzuların çevrelediği benlik tasarım nedeniyle zamanla değişmekte, ciddi çelişkiler ortaya koymakta ve dolayısıyla birçok kimlik sergilenmektedir. Bu durum post-modern insan için sorun olarak görülmez bile çünkü özgürlük ve anlık hazları karşılayan her şey makbul ve meşrudur, bir süre sonra da daha farklı tercihler söz konusu olabilir (Rosenau, 1998: 9798).

Modernizmin her yönüyle tasarlamaya soyunduğu yenidünya düzeninde başat unsurlar olarak kabul ettiği 
rasyonalite, olguculuk, planlama, yönlendirme gibi bireysellik, özgürlük ve faydacılık bambaşka bir sonuca evrilerek tahmin edilemez tehlikelere yol açmıştır. Kural tanımayan bu hareket sadece modernizme karşı durmakla kalmayıp bilime düşman, başka felsefi düşüncelere yönelen ve dini bir uyanışında yolunu açtığı düşünülür (Diggens, 2000: 52). $\mathrm{Bu}$ durum tuhaf karşılanmamalıdır zira modernizmin de kendisi bilimsel, felsefi ve dini anlamda yeni bir düzen teşebbüsüdür. İnsanlık tarafından tecrübe edilmiş ve tatminkâr bulunmadı̆̆ içinde elbette sorgulanabilir ve reddedilebilir. Modern olmanın zorunlu bir kabulü olarak görülmesi beklenen bu süreçler başka bir yeninin işaretleri olarak da değerlendirilebilir.

\section{Tasavvuf Düșüncesi}

Modernizm ve post-modernizm Batı medeniyetinde gelişmiş sistemler olmakla birlikte bütün dünyayı ilgilendiren bir olguya dönüşmüştür. Birbirine karşıtlık arz eden ve içinde bulunduğumuz zaman dilimi içerisinde tecrübe edilen bu iki olgunun çatışması basit bir takım genellemelerle açıklanamaz. Yaklaşık üç yüzyıllık bir geçmişe sahip modernitenin insana birçok fayda sağladığı bir gerçektir. Öte taraftan İslam'ın insan-âlem-Tanrı tasavvuru bağlamında ciddi eleştirilere maruz kaldığını da ortadadır. Ancak bu eleştiriden ziyade kendi içinden çıkardığı büyük bir sorun hatta kaos ve anarşizm olarak tarif edilen post-modernizm üzerine modernite kendisini yeniden gözden geçirmek zorunda kalmıştır. Her şeyin kontrol altına tutulması gerektiği handikabı ile modernizm, hiçbir kesin ölçü ve ölçüt kabul etmeyen sınırsız bir özgürlük ve sayısız doğruluk iddiasıyla karşılaştığı post-modernizme karşı şimdilik yeterli karş1lığı verdiği düşülemez. Zira modernite ussallık koşutunda gelişimi rekabetin varlığı ile sağlamıştır (Ester vd., 1993: 100). Bu durumun bir sonucu olarak kendi rakibini yaratmıştır.

Modern düşünce içerisinde yetişen post-modernistlerin, modernizmin birincil unsurları olan rasyonalite, olguculuk ve materyalizmi kökten sarsacak şekilde yeniden yorumlamışlardır. Aklın her şeyin belirleyicisi, yaratıcısı, doğrulayıcısı olarak kabulü modernizmin geliştirdiği bireysellik, özgürlük ve hümanizm maharetiyle inkâr edilmiştir. Modernizmin gerçeğe ulaşmanın tek yolunun akıl, bilim ve deneyle ispatlanmış zahiri olgular olduğu iddiasının sınırlayıcı ve indirgemeci yaklaşımına karşın postmodernistlerin hiçbir ölçüt ve kesinlik içermeyen bilgi ve geçeklik teorisi ifrat-tefrit çatışması olarak tarif edilebilir. Hakikat bilgisinin sadece aklın belirli ölçütler eşliğinde sadece görünenlerden hareketle elde edilebileceği düşüncesi gerçeklik algısının algı, zaman ve mekâna göre sınırlandırılmasını ifade etmektedir. Post-modernitenin gerçeklik ve doğruluk algısı ise bütün bu nesnel kriterleri göreceli bir şekilde yorumlayarak olguların dahi inkârına yol açmıştır. Dolayısıyla ifrat-tefrit olarak yaşanan bu aşırı hallerin çözümü İslam medeniyetinden neşet etmiş tasavvuf düşüncesinin zahir-batın okuması ile çözülebilir.

İslam inancı yaratılmış her şeyde ilmi bir düzen olduğunu kabul eder. Örneğin “...Herşeyi yaratan ve bir ölçüye göre düzenleyen Allah" (Furkan, 2) olduğu için vahyin Allah'ın ilminin bir nakli olduğu anlaşılır. Âlim olan Allah kâinattaki her şeyi bir ölçüyle yaratmıştır (Rad, 8; Kamer, 49). Bu ayetlerden anlaşıldığı üzere dünyadaki her şeyin ilmi bir dayanağı mevcuttur. İnsanı aklı vesilesiyle halifeliğe yükselten Allah birçok ayette ona gökyüzüne, yıldızlara, ay, güneşe, gece-gündüze, hayvanlara, doğaya bakıp düşünmesini emretmiştir. Çevreye dönük bu gayretin dışında Allah, insana şu soruyu yöneltir, "kesin olarak inananlar için yeryüzünde ve kendi nefislerinizde birçok alametler vardır. Hâlâ görmüyor musunuz?" (Zâriyât, 20-21) Nefis ve onun çeşitleriyle yakından ilgilenen tasavvuf ehli Allah'ın zahir ve batın olarak yarattıkları üzerine tefekkürü bir ibadet saymıştır. Allah'ın isimlerinden olan Zâhir ve Batın, yeryüzünde izhar olurken yaratıkları vesile kılar. Allah'ın kâinatta yaratılış sürecinde algılara açık inkişaf ettirdiği ilmi Zâhir, algılar dünyasının üzerindeki yaratılışında tecelli eden Bâtın ismi Allah'ın ilminin iki vechini ortaya koymaktadır. Meleklerin secde etmesi emredilerek makamı yüceltilen ve yeryüzü halifesi kılınan insanoğlu Allah'ın yaratılış ilimlerinin iki yönünü de kendinde toplayabilmiş tek varlıktır (Konevi, 2012: 24,52). Dünya'nın küçük bir prototipi olarak kabul edilen insan, sufiler tarafindan Allah'ın semaları 7 kat olarak yarattığı gibi 7 nefis mertebesiyle yaratılmıştır. Bu manada Allah'ın ayette bildirdiği "yeryüzünde ve nefislerinizde birçok alamet" hakikati insanda zahir ve batın olarak birleşmiştir.

Gerçekliğin tamamlanması için elzem olan zâhir-bâtın ilişkisini mezceden tasavvufi düşünceyi çözüm olarak gören Guénon'un daire sembolizmi insanın değeri, mizaç farklılıkları ve Yaratıcı ile ilişkisine açıklayarak tasavvuf geleneğinin kurumlarıyla birlikte kozmik ahenge matuf olduğunu ortaya koyar. Dairesel hareketin esas olduğu kâinat çemberinde yarıçap işlevi ifa eden tarikatlar merkezle birleşirler. Dairenin bir tek merkezi olduğu gibi hakikat de tektir. İslam şeriatını kabul ederek dairede yer alan Müslümanlar yaratılış ve mizaç farklılıklarından ötürü birçok yol ve yöntem geliştirerek merkeze doğru yol alan yarıçaplar tesis edebilirler. İslam'ın esaslarıyla çelişmeden, insan çeşitliliğini dikkate alarak zamana ve ihtiyaca göre değişiklikler arz eden tarikatlar dairenin hakikat merkezine doğru uzanan yarı-çaplarlardır. Amaçları bir ancak yöntemleri değişiklik gösteren hakikat/bâtın kanalları olan tarikatlar "Allah'a giden yolların insanların ruhları kadar çoktur" düşüncesinin tecrübe edilebileceği özgürlük ve özgünlük imkânı sağlamaktadır (Guénon, 1989: 30). Tasavvuf düşüncesini, modernizm sonrası insanın buhranlarına çözüm olarak telakki eden batılı bir araştırmacı olarak Guénon tarafindan bu gerçeğin ifade edilmiş olması kendisinin bir tarikat üyesi olması itibarıyla da mühimdir. Zira tasavvufun hal ilmi olması dolayısıyla dinin zahir'den batına doğru olan seyrinde insanın yaşadığı aşkın tecrübelerin hususiliğinin, dinin insan bilincinde ve gönlünde kemale ermesine vesile olduğuna örnek oluşturur.

Peşinden koştuğu mutluluğa erişebilmesi için insanın öncelikle doğru bir kendilik bilincine sahip olması gerekmektedir. Ayetlerde beyan edilen bu gerçeğe modernizme büyük eleştiriler yönelten Seyyid Hüseyin Nasr, insanın mutluluğunun öncelikle kendisine yüklenmiş halifeliği anlamakla sağlanabileceğini belirtir. Ki bu bilinç ile insan, Allah'ın isimlerinin tecelligâhı olan doğru bir âlem algısına sahip olmayla birlikte ile tecellileri kâmil olarak tezahür etme potansiyele olan insan-1 kâmil olma vasfina ulaşarak gerçek saadete erişebilir (Nasr, 2002: 48).

Modernizm zâhire dönük alametleri okumakta büyük başarılar ortaya koymuştur. Ancak uzay, dünya ve dünyanın içerisindekilerin bilimsel olarak her yönüyle ortaya 
konmadığı gerçeğini de göz önünde bulundurduğumuzda zahir ilminin boyutlarının nerelere uzandığını bilemeyiz. Dışa dönük bu okumaların yeterli olmadığının bir ifadesi olarak Allah, insana kendine dair okuma yapmasını tavsiye eder. Çünkü bütün âlemin hizmetine verildiği insanda Allah'ın ilahi bir nefesi olan ruh mevcuttur. Bütün bilimlerin sahibi ve yaratıcı olan Allah, insana hakikat bilgisini ruhuna vahiy ve ilham yoluyla bildirmiştir. $\mathrm{Bu}$ gerçeğin ifade edildiği "Allah göklerin ve yerin Nur'udur.." (Nûr, 35). Bütün kâinatı yoktan ilim ve ölçü ile yaratan Allah, yaratılışın izhar olunup, ilmini anlaşılabilmesi için nura yani insanoğlunu algılarına açık olan zâhiri, manevi haller, duygular gibi bâtıni yönü tarafından da idrak edilebilir hale gelmesi ilmini insanoğlu tarafından akledilebilir kılmıştır. Modernitenin tek yönlü kabul ettiği zâhiri ilimlerin hakikatin tek gerçeklik alanı olduğunu yönündeki indirgemeci özelliği insan fitratı tarafından eksik görülür, post-modern savrulmanın ardından yatan gerçek sebep bu olabilir. Modernizmin ispatlanmış doğrularına rağmen postmodernitenin en azından zâhiren kesinliği ortada olan olguları inkârı mantıksal düzlemde izahtan uzaktır.

Tasavvuf geleneğinin yukarıdaki ayetten hareketle insanın, âlem ve bunların yaratıcısı olan Allah ile direkt bir ilişkisi olmasının kabul etmesi ve bu ilişkiyi maddi ve manevi ilimler bağlamında bir bütünlük arz edecek şekilde açıklaması insanın öncelikle kendilik bilinci geliştirip, Allah ile olan bağından ötürü değersizlik sorununu aşması, günümüz insanın peşinden koştuğu kimlik ve mutluluk probleminin de cevabıdır. İnsanın kendisi, çevresi ve Tanrısı ile sağlıklı bir ilişki kurmasının önündeki en büyük engel tek olan Allah'a inanmamasıdır. Tasavvuf düşüncesinde tevhid sadece iman ile ilgili bir durum olmayıp, düşünsel, duygusal ve eylemsel olarak bütün işlerin Allah'a adanması edilmesi idealidir. Kur'an-1 Kerim'de her işinde Allah'ın rızasını esas olan muttaki, her işinde Allah'ın gözetimi altında olduğu bilinciyle hareket eden muhlisler zümresi tevhidi içselleştirmiş insanları için kullanılır. Tevhid tasavvufi düşüncedeki manasıyla ilgili Cüneyd-i Bağdadi'nin şu açıklaması örnek verilebilir; "Kulun Allah Taala'nın huzurunda bir hayalet ve karaltı gibi olması, İlahi kudretin ahkâmının mecrasında Allah'ın tedbir ve tasarrufunun üzerinde cari olması, bu hal içinde tevhid deryasının dalgaları arasında boğulması, böylece nefsinden, halkın onu kendi işleri için davet etmelerinden ve buna cevap vermekten fani olması, bu fenanın Hakk'a yakınlık makamında Allah'ın vahdaniyet ve vücudunun hakikatine erişilmesi dolayısıyla hâsıl olması, fena halinde Hakk'1 kuldan murat ettiği şeyi bizzat kendisi ifa ettiği için kulun his ve hareketini kaybetmesidir. Yani kulun son halinin ilk hali durumuna dönmesi, olmadan evvel olduğu gibi olmasıdır." (Kuşeyri, 2003: 388).

Tevhid'e ilişkin tasavvuf klasiklerinde sık sık ele alınan fena bulma halinin ilk evreleri olarak telakki edilebilecek inanma ve eyleme geçme boyutundaki eksiklik dolayısıyla modern ile gelenek arasında sıkıșan insanın düşünce sistematiğinin doğru kurulması gerekmektedir. Akla dayanan bilinçli bir tercihin sonucu olarak tevhid evvela "La ilahe" olumsuzlamasıyla düşüncede başlayan kalıpları kırma ve "illallah" ile yeniden ikame etmelidir. Bu manada tasavvufi bilginin kaynağı olan tevhid ile inanan kişi düşünce şekli, zihinsel gayretleri (tefekkür), yürümesi, yemek yemesi gibi zihinsel, bedensel faaliyetlerinden aşkın manevi hallere gibi bütün hayatını tanzim eder. Ki böylece bütünlük arz eden yaşantıyla zahir olandan asıl gaye olan batına doğru yükselişin hayatın zaman üstü manası ve hazzına erişilir (Chittick, 1996: 19). Düşünceyle başlayan tevhid yolculuğunda olduğu gibi modernizmin meydan okumalarına karşı insan ancak fikri bir karşı duruş sergilemek zorunda kalacaktır. Elbette tevhidi düşüncenin doğurduğu eylemsellik aksiyon arz ettiğinde modernizmin ortaya koyduğu yanlışların ardından çözüm olarak kabul görecektir (Nasr, 1995: 90).

İslam inanç sisteminin merkezi olan tevhid ilmin ve bilginin de kaynağıdır. Bütün bilgilerin kendisinde hakiki manasını bulduğu tevhide hijerarşik bir şekilde ulaşıldığını belirten Nasr; melekler, peygamberler, kitaplar gibi vesilelerle kemale eren tevhid dünya-âhiret, zahir-batın'ın uyumlu birlikteliği sayesinde insanın geçmiş ve gelecek bağını sağlam bir şekilde kurabildiği söyler. Modern ve seküler düzenin hâkim olduğu günümüzde insan ile gerçek bilgisinin bağının koptuğu, bu kopuşun kutsaldan uzaklaşmanın ötesinde insanın kendinden uzaklaşması, âlemden uzaklaşması sonucunu doğurmuştur. Hâlbuki insan, tevhidin esasını bildiği zaman kendisinin, Yüce Öz'ün hakikat bilgisine ulaşacağı gibi külli bilme kaynağına ulaşmış olması nedeniyle âleme dair doğru bilgilere de vakıf olabilecektir (Nasr, 1989: 12-19). Buna karşın tevhid şuurundan uzaklaşan insanların birçok tanrılar edineceği bir vakadır. Kur'an-1 Kerim'de hakikat bilgisi kendilerine Allah tarafından bildirildikten sonra insanların aralarındaki haset (Câsiye, 17), kıskançlık (Şûrâ, 14), ihtiras ve aşırlık yüzünden ayrılığa düştükleri bildirilir (Ali İmran, 19).

Post-modernitenin bilgilin kesinliği, nesnelliği, ölçekleri, metodolojisi, yöntem ve teknikleri açısından hiçbir standardı kabul etmemiş olması Kur'an-1 Kerim'de bildirilen aşırılıkların bir ifadesidir. Bunu ifade ederken modernizmin, İslam'ın bilgi kaynağı ile tam bir uyum içerisinde olduğunu ifade etmiyoruz. Zira modernizmin tek yönlü yani zâhiri akla Tanrısal bir hüviyet kazandırması tevhide tamamen aykırıdır. Külli akıl ve ilimden sapmanın bir sonucu olan modernitenin sebep olduğu post-modernite akıl ve bilim konusunda sayısız otoritelerin varlığını ileri sürerek moderniteyi geride bırakmıştır. Zira ölçülük elden bırakılmıştır, ölçülülüğün temel noktası tevhid'dir. Tevhid ya da dinlerin dogmatik yönüne dair eleştiriler bu noktada akla gelebilir. İlmin ve hakikatin tek olduğu kabulünden sonra bütün bilgi ve hikmetin bir yerde toplanması mantıksal zorunluluğu kendiliğinden doğmaktadır. $\mathrm{Bu}$ çıkarımdan sonra dini dogmatiklik açısından bütün varlığı bir ilim ve ölçüyle yarattığını bildiren Allah'ın gerçeği net bir şekilde ortaya koyması ve insanlarında onu uymaları gerektiği, aksi halde ne gibi sonuçlarla karşı karşıya kalınacağını bildirmiş olması aklın sapmalardan arındırılması ve gerçeğe olabildiğince yakın ve kısa sürede erişebilmesi olarak düşünülmelidir. Aksi halde insanoğlu zâhiri doğruları ki modernite nesnellik açısından bu gerçeğe sadık kalmıştır, bâtıni/nefsâni yanlış okumalar yüzünden dengeden uzaklaşılarak gerçeklikten sapmıştır. Sadece tasavvuf değil dinler insana niçin yaratıldığ 1 , nereden gelip nereye gideceğ $\mathrm{i}$ gibi soyut öngörüler eşliğinde bir kimlik sunar (Chevalier, 1993: 10-11). Modernizmin seküler anlayışı sonucu maneviyattan kopuk yaşam tarzıyla birlikte bireylerin bilgiye bakış açısını onun maddi getirisi ile değerlendirilmeye başlanmıştır. Bilginin salt bilgi ve doğru olana götürmesi sonucu elde edilecek erdem ve mutluluk dikkate değer bulunmamıştır. Dolayısıyla bilginin sadece 
zâhiri yönüne odaklanarak tesis edilen modernizm iddiası olan bireyselleşme ve özgürlük post-modernitenin sebebi olmuştur. Allah'ın bütün evrende ortaya koyduğu zâhiri ve bâtıni hakikatleri göz ardı ettiğinde insanoğlunu daima çözüm olarak ortaya koyduğu sapma bir başka sapmanın müsebbiplerinden biri olmaktan öteye geçememiştir. Hâlbuki Kur'an-1 Kerim, tevhid merkezli bir insan-âlemAllah bilinci ve eylem bütünlüğüne sahip Müslümanları aşırlıklardan uzak "ortada yürüyen" olarak tarif eder (Bakara, 143). Ortada yürümenin yeryüzündeki karşılığı ise adalettir. Zira kendi nefsindeki alametleri tevhid ile doğru okuyabilen ve ona göre eylemler ortaya koyan orta yol sahipleri için adalet, tevhidin yeryüzündeki gölgesidir (İbn Arabi, 2007: 181).

Aşırılık ve tepkiselliğin varlık iddiasına dönüştüğü modern dönem, dinin şekillendirdiği geleneksel inanç ve kültürleri akıldan ve bilgiden uzak otomatikleşmiş sistemler olarak tanımlamıştır. Bütün bilgi yolları ve mutluluk kanallarını zahiri/dünyevi olana indirgenmiş olmasıyla Tanrı'dan koparılmış bir gerçeklik algısıyla insanlık felakete sürüklenmiştir (Nasr, 1995: 15-16). Geleneksel düşüncelerin insanı, Tanrı ile birçok yönden ilişkilendirmiş olması nedeniyle yitirilen bu boşluk modern düşüncenin salt zahiri çıkarımlarıyla doldurulamamıştır (Nasr, 1999). Vahiy aracılığıyla hakikatin nakledildiği dini gelenek bilgilenme aracı olarak kabul edilmemiştir. Hâlbuki vahiy yukarıda ayette bildirildiği üzere nurlanma/aydınlanma çeşitli dinler vasitasıyla kendini güncelleyerek tevhidin ve tek olan hakikatin özüne götüren vasıtasıdır (Nasr, 1999: 87-88). Her dönemde insanlığın yaşadığı sıkıntılara çözüm olabileceğini düşündüğü tasavvufun modernizmin tükettiği değerler sisteminin çöküşüyle sorgulanan modenizmin bizzat batılılar tarafindan sorgulandığ (Nasr, 2002: 11). Zira modernizm, başta vahiy olmak üzere dinin zahiri ve batını bütüncül bir yaklaşım içeren akide ve uygulamalarını geçmişte ortaya konmuş bilimsel ve kültürel unsurlarıyla birlikte değerlendiren geleneği inkâr etmiştir (Nasr, 1999: 78-79). Bunun sonucunda hakikat bilgisini ve anlamını yitirmiş vaziyetteki günümüz insanı, kendi varlığının evvel ve ahirine dair tatminkâr cevapları olan kutsalın aktarımını sağlayan gelenekten mahrum kalmıştır (Nasr, 1999: 75).

Modernizmin bilgi ve hakikate dair yanlış saptaması postmodern insanın kendilik algısında aşırıya kaçmasına neden olmuştur. İnsanı maddi ve manevi dualist yapısından koparan modernizm, küresel kapitalizm süreciyle birlikte üretim-tüketim alışkanlıklarıyla değerlendirilebileceği imajını vermiștir. Çünkü tüketim üretim ve tüketim insanın tek hedefi gibi gösterilmiştir. Bunların arttırılması için ciddi bir rekabet sergilenmek zorunda kalan insanoğlu başkalarının sahip olduklarına kıskanmak ve elindekileri korumak için endişe duymaktadır (Fromm, 1997: 30). Mutluluğun ve refahın herkes için ortak bir ideal olarak gösterilmesine karşın bunlara sahip olanı mutlu ederken başkalarıyla paylaşılması söz konusu olduğunda acıya sebep olduğu görülmektedir (Baudrillard, 2004: 2). Modenizmin sebep olduğu bu yaşam tarzının yukarıdaki ayetlerde belirtildiği üzere nefsin terbiye edilmediği durumlarda her bir bireyin tanrılaştırdığı nefsine uygun bir doğruluk algısı tesis ettiği görülür. Yanlış akıl ve bilge kuramının nefsâni hırs, kin, hâsed ve kıskançliklara neden olduğunu ortaya koyan şu âyetler içinde bulunulan durumu özetleyecektir: "Zaten nefisler kıskançlığa hazırdır” (Nisa, 128), "Kim nefsinin cimriliğinden korunursa iște onlar kurtuluşa erenlerdir." (Teğabün, 16).

Modernizm ile post-modernizmin ortak talebi olarak karşımıza çıkan tüketim ve haz çılgınlığının neden olduğu çatışma ve yabanlaşma sorununa tasavvufun ilk olarak ortaya çıktığı zühd evresinde dikkat çekilmiştir. Nefsin doyumsuzluğu, dünya hayatının aldatıcılığı, dünyalığın insanı Rabbi'ne yöneltmek uzaklaştırdığını bildiren ayetlere dayanarak bütün tasavvuf çevrelerince insanın zühdü benimseyerek gönlünü arındırması gerektiği kabul edilmiştir (Kuşeyri, 2003: 208-212). Nefsin tükenmeyen arzularının mekânı olan dünyaya karşı takınılması gereken tavrın vurgulandığı zühd döneminde tasavvufun ilk önderleri için günahlardan uzaklaşmak, mücâhedeyi sürdürmek için bırakın tüketim ve haz çılgınlığını ihtiyaç fazlasını arzulamak düşüklük olarak değerlendirilmiştir. Temel insanı ihtiyaçlarda dahi az ve şüpheli olmayan yetinmek suretiyle hakikat ve mutluluğa eriştiği müşahede edilen bu aktarımlara rağmen lükslerde yarışan modern insanın tükettikçe mutlu olmadığı paradoksuyla karşılaşırız. Daha fazlasına sahip olup tükettikçe geçici hazlara sarılan insan özünde arzuladığı sonsuz mutluluğu zahirin yanlış bilgilendirmesiyle sadece dünyevi eylerde aramaktadır. Bâtıni hazların eksikliğini mütekabil olmayan zahiri nesnelerde aramak gelip geçici olan dünya hayatında cenneti arzulamak gibi boş bir iddiadır. Ancak her insan bu arayışının ardından gitmektedir, zira fitrı olan bu hakikat aslında insanoğlunun kendisine vaad edilen ve özünde istidat olarak ulaşabilme imkânına sahip olduğu sonsuz mutluluğa ulaşmak istemektedir (Nasr, 2001: 103). Modern düşüncenin tatmin edemediği ancak geçiştirdiği bu sonsuzluk arzusuna tasavvufi düşüncede; insanı kandıran, oyalayan yalancı ve geçici hazların nesnesi olmak yerine onlardan ölçüyle istifade etmek suretiyle nasıl ulaşılacağı insani pratiklerle aktarılır.

Post-modern gençliğin imaj ve sanallık üzerinden bir gerçeklik algısı oluşturmalarından özellikle aileler şikâyet etmektedir. Marka ve imaj dünyası olarak adlandırılan bu yeni yaşam tarzı aslında basit bir tercihten ibaret değildir. İlk nazarda aileleri ekonomik sıkıntılara soktuğu için eleştirilen bu gerçeğin arkasında modernitenin fikri desteğini sağladığı tüketim anlayışı yatmaktadır. Ciddi şikâyetlere rağmen gelinen nokta itibarıyla tüketim nesneleri ve onların temsil ettikleri günümüzde bir statü göstergesi olmuştur (Corrigan, 1997: 113-115). Kullanılacak bir eşya olmanın çok ötesinde ürünlerin imaj etkinliği önemlidir (Belk, 1995: 98). Yani kısa süreli bir ihtiyaca karşılık gelmesi beklenen insan tarafından imal edilmiş bir ürün amaç haline dönüşerek ontolojik gerçekliğinden uzaklaştırılmaktadır (Cohen, 1998: 145-146). İnsanoğlunun tevhid ve onun emrettiklerinden saptığında âdete kendi eli ile ürettiklerine taptıklarını gözlemleyebiliriz. Modernitenin aklı Tanrısallaştırmasıyla başladığı bu sürecin sonunda insanın ortak doğrusunun şaşması sonucu nefsine uyarak birçok tanrı üretebileceğini, hatta sapmanın zirvesi olarak bizzat kendisini ilahlaştırabileceğini görürüz. Kur'an1 Kerim'de Allah bu durumu şöyle bildirmektedir; "Hevesini kendine ilah edineni gördün mü?" (Furkan, 3), "Hevâ ve hevesini tanrı edinen, bilgisi olduğu halde Allah'ın kulağını ve kalbini mühürlediği, gözünü perdelediği kimseyi gördün mü?" (Câsiye, 23). Modern ve Post-modern insanın öncelikleri, olmazsa olmazları, değerleri, kimlikleri, benlik algıları, iletişim ve etkileşimleri değerlendirilmeye tabi tutulduğunda ilahi referanslardan oldukça uzaklaşıldığ görülür. Tevhid'in ve nefsâni adanmışlığın timsali olan Hz. 
İbrahim, her kabilenin, ailenin ve hatta kişinin kendi elleriyle yonttukları putlara tapmalarının nasıl bir mantığı olduğunu sormuştur (Saffat, 95). Daha sonra Hz. İbrahim Kâbe'deki putları kırmıştır. Ancak kendisinden sonra yeni putlar üretilmesine engel olamamıştır. Bugün dünyasında dinlerin ve tanrıların ötesinde öneme haiz birçok şey hayatın önceliği ve gayesi olarak kabul edilip putlaştırılabilmektedir. İnsanlık tarihine bakıldığında bu durumun yaygın olduğu görülecektir. $\mathrm{Bu}$ gerçekten hareketle Allah'ın tevhidin önemine dair sık bildirimler yapmasının nedeni anlaşılabilir olmaktadır. Mutasavvıf şair Mevlana nefsin şirk eğilimine dair ayetlere atıfta bulunarak şöyle bir tevil getirmiştir;

\begin{abstract}
"Putların anası nefsinizin putudur. Çünkü o put yılan, bu put ejderhadır. Nefis; demir ve taştan yapılan çakmaktır, put kıvılcımdir. O kıvılcım su ile söner. Fakat taş ve demir (çakmak), su ile söner mi? Ademoğlu'nda, bu ikisi oldukça ne vakit ve nasıl emin olur? Taş ve demir, ateşi içlerinde tutarlar, su onların ateşine işleyemez, tesir edemez. Irmak suyundan haricî ateş söner. Fakat taş ve demirin içine su nasıl girer. Küpün ve testinin suyu fânidir. Lâkin pınarın suyu daima taze ve bâkidir. Ateş ve dumanın aslı demir ve taştır. Hıristiyan ve Yahudi küfrü, ikisinin fer'idir. Put, bir testide gizli kara sudur. Nefsi, muhakkak olarak o kara suya pinar bil. O, yontulmuş put, kara sel gibidir. Put yapan nefis, anayolda bir pınardır. Bir taş parçası yüz testiyi kırar ama pinar suyu durmadan kaynar. Put kirmak kolay, gayet kolaydır. Fakat nefsi kolay görmek cahilliktir." (Mevlana, 2000: 772-778).
\end{abstract}

Allah dıșında insanoğlunun kendi heves ve arzularını güdümünde tanrılar edinmesiyle ilgili olarak İbn Arabi şu tevili getirir;

\begin{abstract}
"Hevâ ve hevesini ilah edineni gördün mü? Allah'ın onu bir ilim üzere saptırmış, kulağını ve kalbine mühürlemiş ve gözünün üstüne perde çekmiştir, şimdi o kimseyi Allah'dan başka kim hidayete eriştirir? Hâlâ ibret almayacak misinız? Hevâ ve hevesini ilah edineni gördün mü?" tutkulu arzularını ibadet edilen bir ilah haline getireni gördün mü?... Bu kimseler hevâlarına uydukları için ona tapmış ve ilah edinmis oluyorlar. Çünkü insanın severek ve itaat ederek kulluk ettiği şey onun ilahıdır, taş dahi olsa. "Allah'ın...saptırdığ l..." halini, istidadının tamamen ortadan kalktığını ve yüzünün süfli cihete döndüğ̈̈nü bildiği için saptırdığı kimseyi gördün mü? Ya da hevâsına tapan bu kimse dinde yapması gereken şeyleri bilen olduğu için Allah'ın onu saptırdığını gördün mü? Bu anlamı elde etmek için "bir ilme göre" ifadesinin "Allah'ın saptırdiğı..." ifadesindeki meful zamire ilişskin hal olarak takdir edilmesi gerekir, faile ilișkin değil. Bu takdirde Allah'in saptırmast, onun bildiğine aykırı hareket etmesinden, Allah'in ayetlerini gözlemlemekten geri durmasından kaynaklanır. Çünkü onun kalbine nefis sevgisi ve hevânin galibiyeti isteği içirilmiştir." (İbn Arabi, 2007: 1150).
\end{abstract}

Tasavvuf düşüncesi insanın doğru bir Allah inancı kurması için öncelikle tevhidi ikmal etmek gerektiğini önceler, bunun önündeki en büyük engel olarak gördüğü nefsin terbiye edilmesi gerektiğini önemle vurgular. Nefsin sınırsız arzu ve istekleri geçici hazları dolayısıyla insanı bağımlı hale getirip adeta insan benliğini köleleştirir. Tasavvuf insanın farkında olmadan, kimi zamanın kendinin kimi zamanda başkalarını ürettiği nefsâni şirk hapishanesinden kurtarmayı gaye edinir (Nasr, 2002: 48). Bunun için de tasavvuf ilmi ilk önce İslam'ın zahiri bilgisini edinmeyi şart koşar. Daha sonra hale yansıtılan bu ilmin istikrarla devam ettirilmesi sonucu keşif, ilmi ilham ve ilm-i ledün olarak ifade edilen zâhir ötesi bilgi edinimi Allah'tan ikram olunur. S1k1 riyazet ve mücahede ile nefsin terbiye edilip zikir ve tefekkürle nefis ve kalbin fitratına uygun hale getirilmesi ilham olarak verilen bu bilgiye Kur'an-1 Kerim'de bazı ayetlerin olduğunu biliyoruz (Bakara, 282; Enfal, 29; Kehf, 65; Hadid, 28). Seyr-û süluk ile elde ilhami olarak ihsan edilen bu bilginin sonucu insan, yaratılmış bütün varlığın hakikatine dair doğru bilgiye erişir ve onlara yönelik eylemlerinde adalet ve ölçüyü elden birakmak, israfa yönelmez.

Post-modernitenin öngördüğü anlık, geçici hazların sorgulanmadan yaşanması sonucu elde edilecek mutluluğun kısa bir süre sonra acı verdiği görülmektedir. İlişkilerin tüketim nesnesi gibi imaj maksatlı bir süre kullanılıp atıldı ğı günümüz insanının yabancılık ve yalnızlık 1zdırabı geçmiştekine kıyasla çok daha fazladır. İnsanla birlikte bütün doğayı kendi hedonist güdüleri uğruna bir araç olarak görme algısına yönlendirilen tüketim insanı aslında kendi Bâtıni yönünü tüketmektedir. Zira insanın Bâtıni yönü yani fitratı diğer insanlar ve âlemden uzak değil bilakis birliktedir. Ancak modernizmin eksik ve indirgemeci tanımlaması sonucu insanoğlu, insanlık ortak değerleri ve doğanın ölçülü yaratılışını inkâr ederek bütün bunların sembolik değerlerini barındıran bâtini yok sayması anlamına gelmektedir ki bu tam anlamıyla yabancılaşma sürecidir. Doğayı da maddi yönü itibarıyla pragmatikçe kullanan rasyonalitenin aksine tasavvufi düşüncede insan ile birlikte âlem ilmi ve ruhani sık1 bir ilişki içerisindedir. Bu nedenle bütün âlem ve doğa kutsal bir niteliğe sahiptir (Nasr, 1982: 10). Dolayısıyla ayetlerde dikkat çekilen doğa ve göksel varlıklar insana kendi konumuyla birlikte var olan düzeni korumak suretiyle nasıl manevi yükselişini gerçekleştireceğini işaret etmektedir (Nasr, 1989: 237).

Tasavvufi düşüncesinde insan nefsi ile vermiş olduğu kademeli mücadele sürecinde aslında âlemi daha iyi tanıyarak onların hakikatlerine dair dual bir öğrenim gerçekleştirmektedir. Karşılıklı bu öğrenmeyle yukarıda kimlik edinimi bahsinde ifade edildiği üzere kendisini yeniden tanıyıp tarif etmektedir. Modern ve post-modern kimlik ediniminden çok farklı olarak bu süreç doğal, iç değerlendirme mekanizmalarıyla birlikte çok yönlü olarak yapılmaktadır. En başta tevhid hakikatinin yer aldığ 1 bu bilgilenme sürecinde $\mathrm{Hz}$. Peygamber örnekliğinde gerçekleştirilir. Hz. Peygamber insan-1 kâmil olması nedeniyle bütün insanlığın ortaya koyabileceği her türlü potansiyeli maksimum seviyede ortaya koyabileceği düşüncesi ile her inanan onda kendisini bulabilecektir (Konevi, 2012: 13-14, 52, 267).

Tasavvufi kurumlar olan tarikatların mistik uygulamalarına bakıldığında her ne kadar dinin zâhiri ile ilgili konularında ortak bir düşünce ve eylemi savunmalarına karşın insan fitratında kaynaklana çeşitliliğe göre farklı yollar benimsedikleri görülür. $\mathrm{Bu}$ bağlamda tasavvuf geleneği içerisinde birçok tarikat, hatta bir tarikat içerisinde birçok kolun ortaya çıktığı görülür. Dinin zâhir ilmine muhalif olmadığı sürece bir şeyhin birden çok halifesinin günün şartları da dikkate alınmak üzere yenileşmeye gittiği doğal kabul edilmektedir. Vahdet-i vücud felsefesini sistemleştiren İbn Arabi (2010), “Allah'a giden yolların sayısının O'nun yaratmış olduğu mahlukâtın nefesleri kadardır" demiştir. Varlıktaki çokluk ve çeşitliliğe tevhid ile cem eden İbn Arabi, bu ifadesiyle her bir insanın yaratılış fitratından getirmiş olduğu farklılıkların anlam bulduğu vahdetin onun 
için özgürlüğünü makbul olduğunu ifade etmiștir. Hatta bireysel farklılıkların yaratılıştan geldiğini kabul eden bu felsefe içerisinden insan zaman ve mekânın standart kalıplarını aşarak hikmetin ve marifetin kaynağı olan Bir'e her an ve şartta ulaşabilmektedir. Zâhir bilgisi ile bireysel sezgisel bilginin mezcedildiği bu mistik tecrübeler, insanın âleme ve onun yaratıcısına dair algılar dünyasının sınırlarını aşarak ruhsal bir aydınlanmayı sağlar (Kaval, 2015: 558). Dolayısıyla tasavvuf felsefesi modernizmin iddia ettiği olguculuğu kozmik bir bütünlükle daha manalı kılmakla birlikte insanın bireysel farklılık ve tercihlerinin değerli olduğunu ortaya koymuştur. Post-modernitenin arzuladığ1 bilginin doğruluğu ve çeșitliliği konusunda fitri bir isyan olarak modernizme getirdiği bu eleştiri tasavvufi zenginlik içerisinde değerli kılınmıştır. Bugün olduğu gibi geçmişteki farklı dinlere ait insanlar tarafindan sevilen Mevlana'da kuşatıcı hakikat bilgisini ifade ederken; "biz ilahi hekimleriz; kimseden tedavi ücreti istemeyiz... Yetmiş iki millet sırrını bizden dinler. Biz, bir perde ile yüzlerce ses çıkaran bir neyiz." (Şimşekler, 2005: 223). İlahi bilginin nuru ile aydınlanmış şahsiyetlerin yeryüzündeki farklılıkları çatışma ve ayrışma sebebi olarak görmediklerinin beyanı olan Mevlana'nın bu ifadesi değişmeyen gerçeğin/tevhid'in âlemdeki kesret/çoklukla zıt düşmediğini göstermektedir. Post-medernitenin savunduğu çok kültürlülük ve sesliliğin Mevlana tarafindan yüzyıllar önce savunulması tasavvufi düşüncenin günümüz çatışmacı atmosferinden dikkate değerdir (Nicholson, 1978: 85).

\section{Sonuc}

Tasavvufi düşünce aracılığıyla dini bilgi ve tecrübenin donuklaşması, taassub ve baskı aracı olmasının da önüne geçilebilmiştir. Zâhir ile çelişmeyen ancak zamanı yakalayabilen tarikatlar sayesinde İslam medeniyeti sosyal, askeri, idari, ekonomik, sanatsal faaliyetleri icra edebilmiştir. Dinin özünü bozmadan günceli yakama gayreti olarak da görülebilecek bu tasavvufi kurumlar insanın bâtini yönünü de doyurarak ahenkli bir yenileşmeyi sağlamışlardır. Tevhid temelinde fitri farklılıklara göre geliştirilen zâhirbatın ahengi insanın bireysellik ve özgürlük yönünde doğru bir şekilde geliştirmesine yardım etmiştir. $\mathrm{Bu}$ nedenle geçmişte yaygın olarak birçok alanda hizmet ifa eden tasavvufi kurumlar doğru birey ve huzurlu bir toplum inşasında etkin rol oynamışlardır. Mesela bugün bencillik ve hedonist olduğu için şikâyet edilen gençliğin fütüvvet teşkilatında kanaatkâr, diğergam ve cömertliğin hizmetkârları olarak istihdam edildikleri görülür. Çünkü Kur'an-1 Kerim'de müminlerin kardeşi olan diğer müminlere yardım konusunda isâr'1 benimseyecek fedâkarlıkta olduklarını bildirir; “... Onlara verilenlerden dolayı içlerinde bir rahatsızlık hissetmezler. Kendileri zaruret içinde bulunsalar bile onları kendilerine tercih ederler. Kim nefsinin cimriliğinden korunursa, iște onlar kurtuluşa erenlerdir (Haşr, 9). Tasavvufi eğitimde nefsin terbiye edilmesinden mürşid ile birlikte salik kardeş olarak bildiği diğer salikleri kendinden ötsün tutmak durumundadır. Onların nefislerinin kendinden üstün olduğu inancı fenâfillah makamına doğru giden birer basamak olarak görülür. Kardeşliğin ve dolayısıyla da tevhidin birey ve toplum hayatında birliktelik ruhunun gelişmesine katkı sağlanmaktadır.
Yine Abbasiler döneminden Osmanlı'ya kadar ribatlarda hem manevi eğitim hem de yeri geldiğinde serdengeçti olarak sınırın ucunda asker görevi üstlendikleri görülür. Tasavvuf ile nefsini, Allah'ın emri ve rızası doğrultusunda eğiterek insan/kul olmanın Allah'ın yaratma ilminde tartışmasız bir gerçekliğini içsel olarak yaşanması sanatsal üretimi de beraberinde getirmiştir. Tıpkı günümüz bilgisinin ekonomiye aktarılması düşüncesinde olduğu gibi sanatında böyle bir sonuca evrilmesi söz konusudur. Kapitalizmin hüküm sürdüğü günümüzde sanat, sanat içindir; sanat, toplum içindir tartışmasının sona erip, sanat; para içindir yorumda karar kılınmıştır. Ancak tasavvufi estetizm ve sanat anlayıșı hiçbir zaman büyük paraların oynadığı sektörel atmosferde başlı başına sembolik bir prestij ürünü olmamıştır. Aksine tevhidi işaret eden itikadi hasiyet içerisinden ilahi ilmin nezaket ve zarafetle gösterilmeye çalışıldığı mütevazı birer örnekler olarak maddi değil manevi boyutu ile hakiki işlevini ifa etmiştir.

\section{Kaynakça}

Afîfî, E.A. (1999). Tasavvuf: İslâm'da Mânevî Hayat. (çev. Ekrem Demirli \& Abdullah Kartal). İstanbul: İz Yayıncilik.

Baudrillard, J. (2004). Tüketim Toplumu. (çev. Hazal Deliceçaylı \& Ferda Keskin). İstanbul: Ayrıntı Yayınları.

Bauman, Z. (1989). Modernity and the Holocaust. Cambridge.

Beckford, J. A. (1966). Postmodernity, high modernity and new modernity: Three concepts in search of religion. In: Postmodernity, Sociology and Religion (pp. 30-47). London: MacMillan Press.

Belk, R. W. (1995). Collecting in a Consumer Society. London and New York: Routledge.

Berman, M. (1988). All That Is Solid Melts +Into Air: The Experience of Modernity. (Second Ed.). London: Penguin.

Best, S. \& Kellner, D. (1998), Postmodern Teori: Eleştirel Soruşturmalar. (çev. Mehmet Küçük). İstanbul: Ayrıntı Yayınları.

Bilgin, N. (2001). Insan İlişkileri ve Kimlik. İstanbul: Sistem Yay.

Bilgin, N. (2007). Kimlik İnşası. İzmir: Aşina Kitaplar.

Buckingham, D. (Ed.). (2008). Youth, identity, and digital media(pp. 119-142). Cambridge, MA: MIT Press.

Chevalier, J. (1993). Din Fenomeni. (çev. Mehmet Aydın). Konya: Din Bilimleri Yayınları.

Chittick, W. (1996). Seyyid Hüseyin Nasr'ın Yazdıkları. (çev. Aysel Danac1). İstanbul: İnsan Yayınları.

Cohen, G. A. (1998). Karl Marx'ın Tarih Teorisi. A. Fethi (Çev.). İstanbul: Toplumsal Dönüşüm.

Connor, S. (2001). Post-Modernist Kültür: Çağdaş Olanın Kuramlarına Bir Giriș. Doğan Şahiner (Çev.). İstanbul: Yapı Kredi Yayınları.

Corrigan, P. (1997). The Sociology of Comsumption. London: Sage Publication. 
Cullenberg, S., Amariglio, J., \& Ruccio D.F. (2001). Introduction in Postmodernism, Economics and Knowledge. London: Routledge.

Detmer, D. (2003). Challenging postmodernism: Philosophy and the politics of truth. Amherst, NY: Polity Books.

Diggens, A. (2000). Run Away World: How Globalization Is Reshaping our Lives. New York: Routledge

Dow, S. (2001). "Modernism and Postmodernism: A dialectical analysis". In: S. Cullenberg, J. Amariglio \& D.F. Ruccio (Ed.), Postmodernism, Economics and Knowledge, (61-76). London: Routledge.

Dunn, G. R. (1998). Identity Crises: A Social Critique of Postmodernity. London: University of Minnesota Pres.

Ellul, J. (1965). The Technological Society. London: Cape.

Faulkner, P. (1990). Modernism. London: Taylor \& Francis Press.

Foster, H. (1983). The Anti-Aesthetic Essays on Postmodern Culture. Washington: Bay Press.

Fromm, E. (1997). Sahip Olmak Ya Da Olmak. Aydın Arıtan (Çev.). İstanbul: Arıtan Yayınevi.

Funk, R. (2006). Ben ve Biz: Postmodern Insanın Psikanalizi. Çağlar Tanyeri (Çev.). İstanbul: YKY.

Giddens, A. (1985). The nation-state and violence (Vol. 2). Cambridge: Univ of California Press.

Giddens, A. (1991). Jurgen Habermas. İçinde: Q. Skinner (Ed.), Çă̆daş Temel Kuramlar, A. Demirhan (Çev.). Ankara: Vadi Yay.

Giddens, A. (2012). Modernliğin Sonuçlart. Ersin Kuşdil (Çev.). İstanbul: Ayrıntı Yayınları.

Guénon, R. (1989). Íslam Maneviyatı ve Taoculuğa Toplu Bakış. Mahmut Kanık (Çev.). İstanbul: İnsan Yayınları.

Habermas, J. (1994). Modernlik: Tamamlanmamış Bir Proje. İçinde: Necmi Zeka (Ed.), Postmodernizm, Gülengül Naliş, Dumrul Sabuncuoğlu \& Deniz Erksan (Çev.). İstanbul: Kıyı Yayınları, 31-44.

Hall, S. (1995). Yeni Zamanların Anlamı. İçinde: M. Jacques (Ed.), Yeni Zamanlar, Abdullah Yılmaz (Çev.). İstanbul: Ayrintı Yay.

Hall, S. (1998). Eski ve Yeni Kimlikler, Eski ve Yeni Etniklikler. İçinde: Kültür, Küreselleşme ve Dünya Sistemi, Anthony D. King (Ed.), Gülcan Seçkin \& Ümit Hüsrev Yolsal (Çev.). Ankara: Bilim ve Sanat Yay.

Harvey, D. (1997). Postmodernliğin Durumu. Sungur Savran (Çev.). İstanbul: Metsi Yayınları.

Harvey, D. (1999). The Condition of Postmodernity. Oxford: Backwell.

Hassard, J. (1999). Postmodernism, philosophy and management: concepts and controversies. International Journal of Management Reviews, 1(2), 171-195.

Hegel, G.W. (2003). Tarihte Akıl. Önay Sözer (çev.). İstanbul: Kabalcı Yay.
Hugman, R. (2003). Professional values and ethics in social work: Reconsidering postmodernism?. British Journal of Social Work, 33(8), 1025-1041.

İbn Arabi (2007). Tefsir-i Kebir Te'vilât. Vahdettin İnce (Çev.). İstanbul: Kitsan.

İbn Arabi. (2010). Özün Özü. İsmail Hakk1 Bursevi \& Sad. Muhammed Bedirhan (Çev.). İstanbul: Hayy Kitap.

Kaval, M. (2015). Nûr Sûresi 35. Ayet Bağlamında Mesenvi'de Nûr Sembolü. Uluslararast Sosyal Araştırmalar Dergisi, 8(38), 1002-1010.

Kellner, D. (1994). Toplumsal Teori Olarak Postmodernizm: Bazı Meydan Okumalar ve Sorunlar. İçinde: Mehmet Küçük (Ed. \& Çev.), Modernite Versus Postmodernite. Ankara: Vadi Yayınları, 227-258.

Kellner, D. (2001). Popüler kültür ve postmodern kimliklerin inşası. Gülcan Seçkin (Çev.). Doğu Batı Ü̧̧ Aylık Düşünce Dergisi, 4(15), 187-219.

Kızılçelik, S. (1996). Postmodernizm Dedikleri. İzmir: Saray Kitabevleri.

King, C. S. (2005). Postmodern Public Administration: In The Shadow of Postmodernism. Administrative Theory \& Praxis, 27(3), 517-532.

Konevi, S. (2012). Fusûsü'l Hikemin Strlarl. Ekrem Demirli (Çev.). İstanbul: İz Yayıncılık.

Kuşeyri, A. (2003). Kuşeyri Risalesi. Süleyman Uludağ (Çev.). İstanbul: Dergah Yayınları.

Lawrance, F. (1989). Habermas and Discourse of Modernitiy: Twelve Lectures. Political Theory, May.

Lewis, P. (2000). Modernism, Nationalism, and the Novel. Cambridge: Cambridge University Press.

Lyotard, J. F. (1985). The Post-Modern Condition. Minneapolis: University of Minnesota Press

McCarty, T. (1991). Habermas ve Modernliğin felsefi Söylemi. İçinde: Q. Skinner (Ed.), Çağdaş Temel Kuramlar, A. Demirhan (Çev.). Ankara: Vadi Yay.

Mevlana Celaleddin-i Rumi (2000). Mevlana-Mesnevî- $i$ Şerîf, Aslı ve Sadeleştirilmişiyle Manzûm Nahifî Tercümesi. Amil Çelebioğlu (Çev.). İstanbul: MEB Yay.

Mourad, R.P., Jr. (1997). Postmodern Interdisciplinarity. Journal of Higher Education, 20(2), 113-140.

Murphy John W. (1995). Postmodern Toplumsal Analiz ve Postmodern Eleştiri. Hüsamettin Arslan (Çev.). İstanbul: Eti Yayınları.

Nasr, S. H. (1989). Íslam ve İlim. İlhan Kutluer (Çev.). İstanbul: İnsan Yayınları.

Nasr, S. H. (1995). Bir Kutsal Bilim İhtiyac1. Şehabettin Yalçın (Çev.). İstanbul: İnsan Yay.

Nasr, S. H. (2001). Íslam ve Modern İnsanın Çıkmazı. Ali Ünal \& Ara Büyükturu (Çev.). İstanbul: İnsan Yayınları.

Nasr, S. H. (2002). Tasavvufi Makaleler. Sadık Kılıç (Çev.). İstanbul: İnsan Yayınlar1.

Nasr, S. H.(1995). Makaleler I. Şehabettin Yalçın (Çev.). İstanbul: İnsan Yayınları. 
Nelson, J. (2001). Feminist Economics: Objective, Activist, and Postmodern. İçinde: S. Cullenberg, J. Amariglio, \& D.F. Ruccio (Ed.). Postmodernism, Economics and Knowledge, (s.286-304). London: Routledge.

Nicholson, R. A. (1978). Islam Sufileri. Mehmet Dag vd. (Çev.). Ankara: Kültür Bakanlıgı Yayınları.

Nyström, H. (2000). The Postmodern Challange - From Economic to Creative Management. Creativity and Innovation Management, 9(2), 109-114.

Richardson, L. (2000). Writing: A method of Inquiry. In: N.K. Denzin \& Y.S. Lincoln (Ed.). Handbook of Qualitative Research, (p.923-948). Thousand Oaks, CA: SAGE.

Rockmore, T. (1989). Modernity and reason: Habermas and Hegel. Man and World, 22(2), 233-246.

Rosenau, P. M. (1992). Post-modernism and the Social Sciences. Princeton. NJ: Princeton University Pres.

Rosenau, P. M. (1998). Postmodernizm ve Toplumbilimleri. Tuncay Birkan (Çev.). Ankara: Bilim ve Sanat Yay.

Simmel, G. (1969). Sociology. Glencoe: Free Press.

Spicer, M. W. (2005), Public Administration Enquiry and Social Science in the Postmodern Condition: Some Implications of Value Pluralism. Administrative Theory\& Praxis, 27(4), 669-688.

Şimşekler, N. (2005). Hz. Mevlana'da Evlilik, Aile ve Çocuk Eğitimi. İçinde: Yeni İpek Yolu Konya Kitabı VI, Caner Arabac1 (Ed.), (s.135-143). Konya: Konya Ticaret Odas1 Yay.

Taylor, C. (1995). Modernliğin Sikıntıları. Uğur Canbilen (Çev.). İstanbul: Ayrıntı Yay. 